\title{
COVID-19 in Kenya
}

\author{
Nancy Mbae ${ }^{1 *}$ \\ ${ }^{1}$ Independent Researcher, KENYA \\ *Corresponding Author: gatwiri84@yahoo.com \\ Citation: Mbae N. COVID-19 in Kenya. Electron J Gen Med. 2020;17(6):em231. https://doi.org/10.29333/ejgm/7896

\section{ARTICLE INFO} \\ Received: 3 Apr. 2020 \\ Accepted: 4 Apr. 2020

\begin{abstract}
COVID -19 meaning Coronavirus disease which is severe acute respiratory syndrome Coronavirus 2 (SARS-CoV-2) discovered in the year December 2019 at Wuhan in China after an outbreak an infectious disease causing respiratory illness - pneumonia. SARS-CoV-2 was previously known as 2019 novel Coronavirus disease or 2019nCov. Kenya has 122 positive cases of COVID-19 as at $4^{\text {th }}$ April 2020, four deaths and three recoveries as reported by the Government of Kenya.
\end{abstract}

Keywords: COVID-19, SARS-CoV-2, Coronavirus disease

\section{INTRODUCTION}

COVID-19 virus is spread from person to person through droplets when an infected person coughs, sneezes or talks, the virus particle is inhaled through nose or mouth. The virus can also be transmitted through touching an infected objects or surfaces like doorknob, computer or table and then touching eyes (1). It's good to note that a study done by scientists in Singapore found out that transmission through tears is low since out of 64 tear samples collected from 17 patients between day two and twenty from initial samples were tested and patients monitored for 20 days, none of them showed conjunctivitis or red eyes. Symptoms like fever, fatigue, dry cough, sputum/phlegm production, shortness of breath, sore though and headache. Evidence states from China that Person may be positive for COVID-19 but asymptomatic (2).

The disease was declared a Public Health emergency International Concern by on 30 January after the disease was reported from five World Health Organisation (WHO) regions in a span of one month (3). Africa as a continent recorded its first case of the virus on 14 February 2020 from Egypt. Due to the Virus continued spread across continents except Antarctica that is in 114 countries and killing over 4000 people by 11 March 2020, WHO chief Tedros Adhanom Ghebreyesus therefore declared first pandemic caused by Coronavirus (4). Pandemic declaration came two days before Kenya announced its first confirmed case of COVID-19 from a 27 year-old woman who had travelled to Kenya from United States via London on 5 March 2020. On 17 March 2020, Kenya confirmed two more cases of COVID-19 of passengers who sat next to the first case on transit from United stated. The cases have increased gradually and by 4 April 2020, 110 positive cases had been reported by Government of Kenya, Ministry of Health services as positive for COVID-19 as shonw in Figure 1.

One case of the woman who first tested positive reported to have recovered on 25 March 2020 and two more cased recovered by 1 April 2020. Four deaths from the SARS-COV-2 have been reported in the country.

Covid - 19 brought confusion and stress to Kenyans as well as affecting day to day running of activities in the country. Underemployment and unemployment have increased to-date since confirmation of first Covid-19 case with questions of where will Kenyans who live from hand to mouth get essential/basic necessities from? May theft increase due to unemployment?

On 15 March 2020 when cases rose to three, Kenyan President closed all learning institutions with directives issued to public and private sector workers to work from home while measures to protect and prevent infection by COVID-19 emphasized. Economy the country and living standards of people have not been spared but shaken with retail and wholesale traders increasing prices for food and personal health items like sanitizers.

As COVID-19 threat continued, more strict measures were put in place to help Kenyans cope with the effects of the pandemic virus by the Government. They included Curfew starting 27 March 2010 starting 7pm to 5am, 100\% tax relief to Kenyans earning KSh 24,000 and below, Pay as you earn (PAYE) and VAT reduction from a maximum of $30 \%$ to $25 \%$ and $16 \%$ to $14 \%$ respectively, temporal suspension of loan defaulters, reduction of turnover tax rate from $3 \%$ to $1 \%$ for all micro, small and medium enterprises and of resident income tax to $25 \%$, KSh 10 billion (US\$95 million) to vulnerable groups including the elderly and orphans was made available, pay cuts of $80 \%$ on President and Deputy President salaries, all Cabinet Secretaries to take $30 \%$ pay-cuts, Chief Administrative Secretaries (30\%) and Principal Secretaries (20\%) and recruitment of 5000 health workers to help in management of the Corona virus disease in the country.

Due no pharmaceutical treatments in place or vaccine for COVID-19, high rate of transmission of this virus is expected which will lead to great challenges to control the spread of the disease (5). Kenya, therefore, has impacted on health 


\section{COVID - 19 CASES IN KENYA}

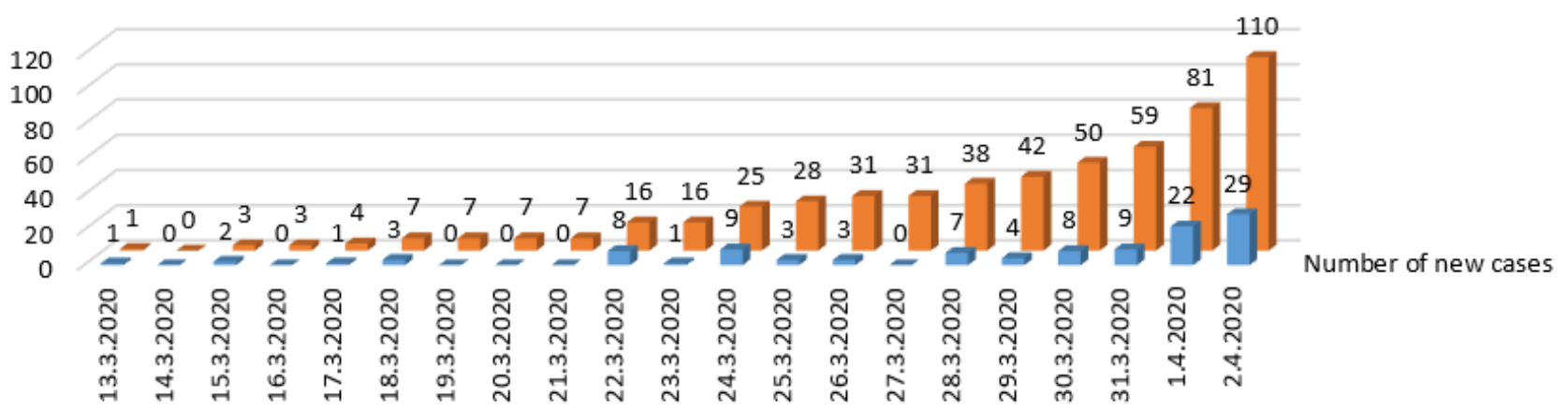

Number of new cases

frequency of cases

Figure 1. COVID-19 new cases daily and cumulative

promotion in every county and contact tracing on suspected by health workers, paramedics with help of security officers. Televisions have also modified cartoon adverts to teach children on how dangerous Coronavirus disease is, washing hands with soap and running water, when sneezing/coughing to use tissue paper then throw it away or to use flex elbow and no greeting people by hands. Minister for health in Kenya announced on 4 April 2020 that everyone need to put on face mask if he/she has to go out of the home to open air with the hope of "Together we shall overcome". There many contradicting information on the websites on when, why and who should use the face mask thus limitation the use of the item as a precaution measure for preventing getting infected by Coronavirus.

Majority of Kenyans are not adhering to the strict measures put into place to curb spread of COVID-19 especially Curfew, keeping social distance, COVID-19 cases are therefore expected to rise exponentially. Curbing mankind behavior and stopping spread of COVID-19 will be a difficult phenomenon noting from 5 am to $7 \mathrm{pm}$ Kenyans are free to do all they need to do. Entertainment places (Pubs and clubs) regardless of the order issued by Government that they should remain closed until COVID-19 pandemic is over, operations are ongoing as usual.

Question is when will the Government impose total lockdown before reaching an uncontrolled and over whelming COVID-19 cases?

Behavior change calls for paradigm shift and understanding of the lock in requires dynamics of sustaining people and better knowledge of how the country will be governed. Nevertheless, outcome of the current COVID -19 currently in Kenya depends on governance systems in an increasingly neoliberal world that closes off avenues for envisioning possible worst-case scenarios.

\section{CONCLUSION}

COVID-19 has changed the way things work globally especially interactions socially and economically. Results shows that all countries, departments and sectors and with every individuals should work together to help fight the virus. Each person should take his/her own responsibility by following all the World Health Organization and measures put across by Ministry of Health in each country to help succeed in eradicating the disease regardless of the conflicting information from different organization on who, why and when to use face masks. This study opens up more research needed to find out correlation between perceptions and capability towards behavior change on COVID 19 as well as exploring more types and use of face masks.

\section{REFERENCES}

1. Yu Jun IS, Anderson DE, Zheng Kang AE, Wang L-F, Rao P, Young BE, Lye DC, Agrawal R, Assessing Viral Shedding and Infectivity of Tears in Coronavirus Disease 2019 (COVID-19) Patients, Ophthalmology (2020). https://doi.org/ 10.1016/j.ophtha.2020.03.026

2. Day M. Covid-19: Four fifths of cases are asymptomatic, China figures indicate. BMJ 2020;369:m1375. https://doi.org/10.1136/bmj.m1375 PMID:3224188

3. UN NEWS. Global Perspective Human Stories: China shows COVID-19 Coronavirus can be 'stopped in its tracks' Available at: https://news.un.org/en/story/2020/03/ 1059502 (Accessed on 1 April 2020).

4. British Broadcasting Corporation. COVID 19: The History of Pandemic Available at: https://www.bbc.com/future/ article/20200325-covid-19-the-history-of-pandemics (Accessed on 1 April 2020).

5. Khosravi M. Perceived Risk of COVID-19 Pandemic: The Role of Public Worry and Trust. Electron J Gen Med. 2020;17(4):em203. https://doi.org/10.29333/ejgm/7856 